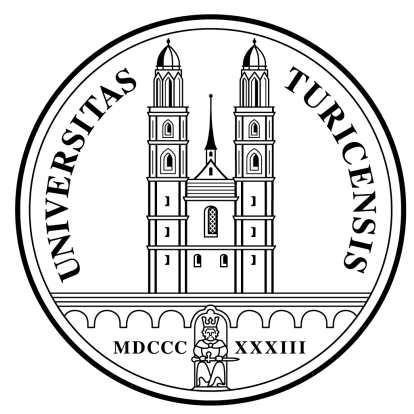

Institute for Empirical Research in Economics

University of Zurich

Working Paper Series

ISSN 1424-0459

Working Paper No. 113

\title{
Moral Property Rights in Bargaining
}

Simon Gächter and Arno Riedl

January 2002 


\title{
MORAL PROPERTY RIGHTS IN BARGAINING*
}

\author{
Simon Gächter ${ }^{\ddagger}$ and Arno Riedl ${ }^{\S}$
}

April 25, 2002

\begin{abstract}
In many business transactions, in labor-management relations, in international conflicts, and welfare state reforms bargainers seem to hold strong entitlements that shape negotiations. Despite their importance, the role of entitlements in negotiations has not received much attention. We fill the gap by designing an experiment that allows us to measure the entitlements and to track them through the whole negotiation process. We find strong entitlement effects that shape opening offers, bargaining duration, concessions and reached (dis-)agreements. We argue that entitlements constitute a "moral property right" that is influential independent of negotiators' legal property rights.
\end{abstract}

JEL Classification Number: A12, D63, C78, C92

Keywords: Moral property rights, fairness judgments, bargaining with claims, selfserving bias

\footnotetext{
*This paper is part of the EU-TMR research network ENDEAR (FMRX-CT98-0238) and the research project on "Strategic Bargaining and Coalition Formation" financed by the Oesterreichische Nationalbank (project number: 6933). We are very indebted to Franz Brandel who wrote the experimental software. Caroline Eckhart, Monika Egelwolf, Helmut Elsinger, Markus Knell, Armin Schwienbacher and Jana Vyrastekova provided excellent research assistance. We especially thank Jonas Agell, Wulf Albers, Marc Bettzüge, Iris Bohnet, Gary Bornstein, Colin Camerer, Rachel Croson, Martin Dufwenberg, Catherine Eckel, Armin Falk, Ernst Fehr, Lorenz Götte, Heike Hennig-Schmidt, Guillermina Jasso, James Konow, Michael Kosfeld, Barbara Krug, Axel Ockenfels, Roald Ramer, Elke Renner, Tom Rietz, Bettina Rockenbach, Bradley Ruffle, Randolph Sloof, Jean-Robert Tyran, Bodo Vogt, Nick Vriend and participants of conferences and seminars in Amsterdam, Bari, Barcelona, Bielefeld, Erfurt, Lake Tahoe, Mannheim, New Orleans, Stockholm and Zurich for their helpful comments.

${ }^{\ddagger}$ CESifo and University of St. Gallen, FEW-HSG, Varnbüelstrasse 14, CH-9000 St. Gallen, Switzerland. email: simon.gaechter@unisg.ch

${ }^{\S}$ University of Amsterdam, CREED, Faculty of Economics and Econometrics, Roetersstraat 11, NL-1018 WB Amsterdam, The Netherlands, e-mail: riedl@fee.uva.nl
} 


\section{Introduction}

In many negotiations bargainers seem to bring strong entitlements to the bargaining table. By drawing on many examples both from the laboratory and the policy arena, Zajac [1995, p. 121] argues that the "sense of ownership in the status quo is a commonplace phenomenon. Feelings about the justness of such ownership rights may swamp feelings that equality should prevail." The long-lasting Israeli-Palestinian conflict also illustrates the importance of entitlements - in this case on pieces of land [Feith, 1993]. Entitlements are also important in ordinary business relations. In their seminal paper, Kahneman, Knetsch and Thaler [1986, p. 729] provide survey evidence that many business transactions are characterized by a "principle of dual entitlement, which governs community standards of fairness: Transactors have an entitlement to the terms of the reference transaction, and firms are entitled to their reference profit" (italics in original). Bazerman's [1985] study on wage arbitration illustrates the power of this argument. Likewise, Hicks [1974, p. 63] has argued "that the system of wages should be well established, so that it has the sanction of custom. It then becomes what is expected; and (...) what is expected is fair" (emphasis added). As a last example, consider the entitlements generated by the welfare state and how they shape attitudes on necessary reforms (e.g., Lindbeck [1995]; Romer [1996]; Boeri, Börsch-Supan, and Tabellini [2001]).

The common thread in all these examples is that entitlements seem to strongly shape negotiations. These entitlements may sometimes even spark off conflicts. Despite the importance and prevalence of casual observations that entitlements are crucial in bargaining, there is not much systematic evidence available. The main goal of this paper is to fill this gap by providing empirical insights from controlled experiments into how entitlements shape negotiations. For the purposes of our paper Schlicht [1998, p. 24] provides a very succinct definition of an entitlement, and its counterpart, an obligation:

"Entitlements are rights, as perceived by the individual. They are not, however, abstract legal rights. Rather they denote the subjectively perceived rights that go along with a motivational disposition to defend them. Obligations are the counterparts of entitlements. They refer to claims of others that are subjectively accepted, and go along with a motivational disposition to respect these claims" (italics added).

To study the role of entitlements in negotiations we introduce as our workhorse an experimental two-person "bargaining with claims" environment. A bargaining problem with claims is a standard bargaining problem [Nash, 1950] enriched with a "claims point', i.e., a claim on a certain share of the pie that lies outside the feasible set. ${ }^{1}$ In our experiment subjects first acquire claims in a competitive task. With a certain probability these claims are actually paid out to the subjects. With the remaining

\footnotetext{
${ }^{1}$ See O'Neill [1982]. Chun and Thomson [1992, p. 20] illustrate their meaning of claims by an example of a labor-management negotiation: "(...) labor and management come to the negotiation table with certain expectations, or with certain claims. These expectations may have been formed by observing the resolution of similar conflicts in related industries but may not be mutually compatible in the actual situation; the claims may represent commitments made to the agents in earlier negotiations which, because of changes in the industry that may have adversely affected the feasible set of the firm, cannot all be honored any more".
} 
probability subjects are told that the claims are sunk and that they have to negotiate an agreement in a completely symmetric free-form bargaining over a computer net. In case they fail to reach an agreement, they earn nothing. Our bargaining with claims environment is thus a stylized representation of the above examples. To learn about the entitlement bargainers derive from the sunk claims, negotiators, before they start to bargain, are asked in private what they think a fair settlement from the vantage point of a neutral arbitrator is.

Our research design allows us to study several important issues. First, we can investigate which entitlements bargainers actually derive from the sunk claims. Second, since entitlements are subjectively held fairness judgments, it is likely that they are not consistent in the sense that all entitlements can be satisfied without some curtailment by at least one bargaining party. This poses the question how possibly inconsistent entitlements influence the negotiations. Our experimental design allows us to track the impact of entitlements through all phases of a negotiation - from the opening offers, the concessions and bargaining duration, to the reached agreements and disagreements.

Our paper makes three contributions that go considerably beyond the existing literature. First, we study sunk claims and the entitlements they create. Consistent with the introductory examples we find that the sunk claims strongly shape the entitlements people derive from them. Second, previous research on entitlements has concentrated on strategically asymmetric one-shot games like ultimatum and dictator games, where entitlement effects may also be confounded with strategic effects. By contrast, we study entitlements in a symmetric and also more realistic full-fledged bargaining problem. Third, we link elicited entitlements to all phases of a negotiation. The strategic symmetry of our bargaining problem and the free-form bargaining load the dice against finding entitlement effects in bargaining behavior. Despite this, we observe that entitlements strongly influence negotiations, which sheds new light on old bargaining phenomena: (i) We find that opening offers are not only determined by strategic considerations but reflect as well the entitlements. (ii) Tensions in entitlements held by the negotiators prolong negotiations and are a significant reason for the often-observed "deadline effect" of last-minute agreements. (iii) We also find that the perceived entitlements shape the concessions that are necessary to strike an agreement. (iv) Reached agreements strongly reflect the perceived entitlements.

Research on the importance of distributional fairness has made great progress in recent years (see e.g. Hoffman and Spitzer [1985], Konow [1996, 2000, 2001], and Rutström and Williams [2000]; see Camerer [forthcoming] for an overview of bargaining experiments). However, to the extent that previous research has investigated entitlements (see Section V), it was mainly concerned with how the 'legal property rights', and the way they are acquired, influence the entitlements people derive from them. Because entitlements complement the legal property rights, it is useful to term them a 'moral property right'. Yet, a legal property right is often asymmetric in that one person holds it and another does not. Thus, the moral property right that comes with a legal property right is confounded with the strategic aspects of the latter. The advantage of our setup is that it highlights a situation where the legal property rights are completely symmetric, once negotiations have to take place. Hence, in our experiment, any entitlement people derive from the sunk claims cannot be confounded with the strategic aspects of the legal property right. Our findings suggest, therefore, that 
entitlements constitute a moral property right that exists independently of the legal property rights.

\section{Experimental Setup}

The main purpose of our study is to investigate how entitlements derived from sunk claims shape negotiations. Therefore, our experimental design consists of three ingredients: (i) negotiations in a 'bargaining with claims' experiment, (ii) the implementation of claims, and (iii) the measurement of entitlements. A sample copy of the instructions is available at http://www.fee.uva.nl/creed/pdffiles/InstrToMPR.pdf.

\section{A. Features of the Experimental Design}

The 'bargaining with claims' environment. At the beginning of the experiment subjects were randomly and anonymously paired and introduced to the bargaining problem. To make the experimental task cognitively easy and to enhance the perceived symmetry of bargaining roles, we cast the bargaining as one between two 'heads of departments' in a hypothetical firm that consists of two departments. ${ }^{2}$ Subjects were told that in this firm the total budget available for both salaries is 2490 'points'. (In the experiments 1 point was worth 0.1 Austrian Schillings (ATS). Hence, the salary budget was worth 249 ATS $(\approx \$ 21)$.) The instructions said that the firm's previous policy always has been to grant the better-performing head of department a higher share of the total salary budget (1660 points) than the lower-performing head of department (830 points). However, there is now the possibility that - due to exogenous factors beyond the control of the firm - economic conditions for the firm become worse and the salary budget will have to be cut to 2050 points. The firm states that, should this case materialize, it will not impose any sharing of the new salary budget onto the managers. Instead the firm asks the heads of departments to bargain among themselves to reach an agreement of how to split the new salary budget. If they reach an agreement it is implemented and each head of department will receive the agreed share. The subjects were also told that they are 'fired', i.e., will not earn any money in the experiment except the promised show-up fee should they fail to reach an agreement.

In case the salary budget does not shrink, the bargaining partners are paid according to the previous wage policy: the manager with the better performance will receive a salary of 1660 points, whereas the manager with the inferior performance will receive a salary of 830 points. Whether the salary budget is 2490 or 2050 is determined by chance.

Notice that this story - in the case where the salary budget shrinks — depicts a bargaining with claims problem. In the case where the lower salary budget becomes

\footnotetext{
${ }^{2}$ Pilot experiments with a completely context-free framing revealed that many subjects found the experiment too artificial. For example, one participant said that he had problems to seriously think about and engage in the bargaining because of the artificiality of the whole setup. Such a reaction is completely in line with findings in cognitive psychology that highlight that reasoning without context is very hard, if not impossible (see, e.g., Ortmann and Gigerenzer [1997]). Another advantage of the explicit framing is that it increases control over the context. If the experiment is context free, subjects may try to find similarities to their experiences outside the lab, which are beyond the control of the experimenter. For these reasons we decided to put the experiment into the context of a mildly framed hypothetical firm bargaining problem.
} 
relevant, the sum of both 'claims' (read 'historically implemented sharing of the salary budget') lies outside the bargaining set. The conflict payoff of the bargaining problem, is $(0,0)$.

The implementation of claims. In the experiments we explained the 'performance measurement' as follows:

"In this experiment performance will be measured with a general knowledge quiz. The department head who gives correct answers to a greater number of questions than the other department head has shown the better performance, and has therefore, given the firm's previous policy, earned a salary claim of 1660 points. The department head with the lower performance previously received a salary of 830 points."

The "general knowledge quiz" consisted of sixteen questions from a variety of fields, including astronomy, history, sports, music, politics, etc. We were very careful to select questions that students with a high school degree should in principle be able to answer, and that subjects would recognize as testing their high school knowledge. The knowledge quiz was a multiple choice test with five possible choices and only one correct answer. All subjects had to answer the same questions. They had eight minutes to answer the questions. Unanswered questions were counted as wrong answers. ${ }^{3}$

After the quiz we told the subjects which of the two bargaining partners did better in the knowledge quiz. We only informed them about the rank of their performance and not about the actual number of correct answers. Apart from simplicity reasons, we wanted to hold the claims constant across subjects and between bargaining pairs.

Recall from the description of our bargaining problem that a chance move determines whether the salary budget shrinks to 2050 points or stays at 2490 points, where the latter outcome implies that the claims according to the knowledge quiz are actually paid out. In the experiment the chance move was implemented as follows. After subjects were informed about the rank of their performance, each bargaining partner in a dyad had to roll a six-sided die. It was explained that the claims would be actually paid out if the sum of the numbers of both dice was greater or equal to eleven. If the sum of the dice numbers was smaller than 11, the bargaining partners had to bargain over how to split the new salary budget of 2050 points.

There are two reasons why we implemented this chance procedure. First, by making the claims a potential payment in the experiment, we gave the subjects an incentive to see the knowledge quiz as an important part of the experiment. Second, our main research interest is to investigate the impact of perceived entitlements on bargaining outcomes. We therefore set the probability that bargaining actually had to take place to $11 / 12$.

In this context it is important to notice that in the bargaining over the reduced salary budget any entitlement effect can only be of a psychological nature. Moreover, differences in the perceived entitlement cannot be due to any self-serving assessment

\footnotetext{
${ }^{3}$ Previous research suggests that a knowledge quiz is indeed viewed as representative of true desert (see e.g., Hoffman, McCabe, Shachat and Smith [1994]; Clark [1998]; Ball and Eckel [1998]; Ball, Eckel, Grossman and Zame [2001]).
} 
of roles, since bargaining roles are completely symmetric. Our framing of the experimental task as a negotiation of two department heads was chosen to maximize the likelihood that subjects perceive their roles as being completely symmetric, apart from the difference in performance in the knowledge quiz.

Measurement of entitlements. All subjects in the experiment had to answer the following question (adapted from Babcock, Loewenstein, Issacharoff and Camerer [1995]):

"According to your opinion, what would - in case of the bad economic condition for the firm - be a 'fair' distribution of the salaries from the vantage point of a non-involved neutral arbitrator? (Please use exact amounts; no intervals! The amounts have to sum up to 2050 points!)" (emphasis in original.)

In the remainder we will refer to this question as the 'arbitrator question'. The fairness judgments we receive as answers to this arbitrator question inform us on the perceived entitlements and obligations of our subjects. In the main part of the paper, we will link the fairness judgments to the negotiation behavior.

\section{B. Experimental Procedures}

Table 1 summarizes the sequence of events. After subjects arrived at the lab, we randomly allocated them to computer booths, which were located in two different rooms. Each subject's bargaining partner always was in the other room. Subjects first read the experimental instructions that introduced them to the bargaining problem and the performance measurement. After subjects had finished reading the instructions they answered the knowledge quiz and rolled the dice to determine whether the claims will be paid out or whether they have to bargain over 2050 points. In case the dice determined that the claims will be paid out, we told the pairs to bargain hypothetically over the sharing of 2050 points. We ensured the subjects that they will receive their claims regardless of the outcome in the hypothetical bargaining. ${ }^{4}$ Right before the start of the negotiations we announced the arbitrator question. We told the subjects that no other participant of the experiment will be informed about their answer to this arbitrator question.

The bargaining was free-form, i.e., there was no fixed bargaining protocol (see, e.g., Roth and Murnighan [1982]). Bargaining was conducted over the computer net with the help of the experimental software "Rabbit" developed by Brandel [1998]. The negotiators were allowed to make any (non-negative) proposal as long as the sum of shares was smaller or equal to 2050 points. Subjects also had the possibility to send messages along with a proposal (as long as these messages did not contain threats or did reveal the identity of the sender, which was checked by an experimenter). Mere messages without a proposal were not possible. The negotiators had 15 minutes to reach an agreement. The instructions told the subjects that in case they fail to reach an agreement or exceed the strict time limit of 15 minutes (900 seconds) they will

\footnotetext{
${ }^{4}$ This procedure ensured that no bargaining pair left earlier than the others, which would have been technically difficult and disturbed the experiment. Moreover, the comparison of hypothetical and real bargaining allows us to check the importance of monetary incentives for the bargaining outcome. However, we actually observed only one pair that had to bargain hypothetically.
} 


\begin{tabular}{|c|c|}
\hline 1. & Reading of instructions \\
\hline \multirow[t]{2}{*}{2.} & $\begin{array}{l}\text { Quiz determines claims and } \\
\text { subjects are informed about them }\end{array}$ \\
\hline & $\left(\begin{array}{c}1660 \text { points for "winner" } \\
830 \text { points for "loser" }\end{array}\right)$ \\
\hline 3. & $\begin{array}{l}\text { Nature determines whether } \\
\text { claims are paid out or if } \\
\text { bargaining over } \\
2050 \text { points takes place }\end{array}$ \\
\hline 4. & Arbitrator question \\
\hline 5 . & $\begin{array}{l}\text { Free-form bargaining } \\
\text { over } 2050 \text { points } \\
\quad \text { (max. } 900 \text { sec.) }\end{array}$ \\
\hline 6. & Post-experimental questionnaire \\
\hline 7 . & $\begin{array}{c}\text { A further experiment } \\
\text { (includes steps } 2,3,5,6 \text { ) }\end{array}$ \\
\hline \# of pairs & 45 \\
\hline
\end{tabular}

earn nothing from this experiment, except their show-up fee. Hence, the 'threat point' in this experiment is $(0,0)$. Random pairing, anonymity, duration and disagreement payoffs were common knowledge.

There are two reasons why we chose free-form bargaining instead of a fixed bargaining protocol. First, we wanted to separate possible entitlements effects from strategic effects in the bargaining. Therefore we made both bargaining partners strategically equally strong. A symmetric threat point and no obvious 'first (or last) mover advantage' through free-form bargaining are helpful in achieving this goal. Second, a strict bargaining protocol would have rendered the observation of claim-specific behavioral patterns more difficult.

After the bargaining we administered a questionnaire which asked the subjects a couple of questions about their socio-economic characteristics, their motives in the experiment, and their attitudes towards the quiz and the claims.

After subjects had completed the post-experimental questionnaire, we announced a further bargaining experiment in which we formed new bargaining pairs, conducted a quiz with sixteen new questions, and then proceeded with points 3 and 5 of Table $1 .{ }^{5}$ The purpose of this experiment was to test the stability of our findings. We will shortly discuss the results of this second experiment in Subsection III.C.

We conducted the experiments in the computerized lab of the Institute for Advanced Studies in Vienna. Ninety subjects participated in eight experimental sessions. Our subjects were first year undergraduate students of law, business administration and computer science. Each session lasted approximately two hours. The average earning (including a show-up fee of ATS 70.-) per subject was approximately ATS $255,-(\approx 21 .-)$.

\footnotetext{
${ }^{5}$ We did not ask the arbitrator question again, because (i) subjects already provided an answer in the first experiment and (ii) because new answers would not have been independent of the first answer.
} 


\section{Results}

We will first set the stage by presenting the results of the fairness judgments according to the arbitrator question. Then we will move on to first explain the bargaining process (opening offers, bargaining duration, and concessions), and then the agreements and disagreements as a function of the entitlements.

For convenience, we will in the remainder of the paper refer to the subject with the claim of 1660 (830) as the 'winner' ('loser') of the performance quiz. Moreover, we will adopt the convention to express all allocations in 'winner shares', i.e. the share of the total pie of 2050 that goes to the 'winner' of the quiz, regardless whether this proposed allocation was made by a winner or a loser.

\section{A. The entitlements}

"What is fairness? Well, unless you are going to take the position that everyone should earn the same thing, fairness is going to be arbitrary."

W. Buckley [Tucson Citizen, 3/17 1992], quoted after Zajac [1995, p. 101].

From an ex ante point of view, there are at least two natural 'focal points' in our bargaining with claims experiment once negotiations are necessary. If negotiators perceive the claims as irrelevant, a likely focal point given the strategic symmetry of bargaining partners is the equal split of the reduced pie. In contrast, if subjects - in light of Schlicht's [1998] definition - perceive the sunk claims as having created perfectly legitimate entitlements and obligations on a particular share of the pie, a second focal point is the proportional split according to the claims. The proportional split would entitle the winner to a share of $2 / 3$, which the loser would feel obliged to accept. A loser would then only be entitled to a share of $1 / 3$ of the reduced pie of 2050 points. ${ }^{6}$ Thus, we take an observation that fairness assessments are close to the equal split as evidence against the importance of a claim-related entitlement effect; fairness judgments that give the winner more than the equal split - and in particular in the vicinity of the proportional split - would suggest a strong entitlement effect.

However, entitlements may also be role-specific in that winners and losers arrive at different fairness judgments. For example, it is well known from psychological research that people tend to attribute their success to their skill but believe that failures are largely due to bad luck (see Zuckerman [1979]). ${ }^{7}$ If losers attribute their low claims to bad luck and winners to their skills they may regard the equal split or the proportional split, respectively, as the fair outcome.

\footnotetext{
${ }^{6}$ In our bargaining problem the two focal points can also be derived from normative solution concepts of cooperative bargaining games (see Thomson [1995] for a survey). Konow's [1996, 2000, 2001] "accountability principle" also predicts the proportional split. In our context the accountability principle demands that the entitlement is proportionate to the performance in the knowledge quiz and that bargainers are not held responsible for the bad luck of having to negotiate over a reduced pie. See also the closely related concept of equity theory [Selten, 1978], or Zajac's [1995, Chap. 10] discussion of "The Formal Principle of Distributive Justice".

${ }^{7}$ Indeed, we find evidence for such an attitude among our subjects. In our post-experimental questionnaire we asked the subjects to express on a 7-point scale the degree of their agreement with two statements that tried to capture such biased judgments ( $1=$ 'completely true'; $7=$ 'not at all true'): "In a knowledge quiz like this it is at random who answers more questions correctly" and "Who has the better general knowledge will answer more questions correctly". In question 1 the average answers of losers and winners, are 4.0 and 4.8 respectively, $(p=0.013$, one-sided t-test). In question 2 , the average answers of losers and winners are 2.1 and 2.5 , respectively ( $p=0.078$, one-sided t-test).
} 
Table 2 - Summary Statistics of Fairness Judgments

\begin{tabular}{|c|c|c|c|}
\hline & \multicolumn{3}{|c|}{ ARBITRATOR QUESTION } \\
\hline Definition & \multicolumn{3}{|c|}{$\begin{array}{l}\text { "According to your opinion, what would be } \\
\text { a 'fair' distribution of salaries from } \\
\text { the vantage point of a non-involved } \\
\text { neutral arbitrator?" }\end{array}$} \\
\hline Variable & \multicolumn{3}{|c|}{ Expressed in 'winner share' } \\
\hline Admissible range & \multicolumn{3}{|c|}{0 to 100 percent } \\
\hline & & \multicolumn{2}{|c|}{$\mathrm{N}=90$} \\
\hline & & Mean & Std. dev. \\
\hline & Winner & 64.0 & 6.21 \\
\hline & Loser & 61.6 & 6.78 \\
\hline & Combined & 62.8 & 6.58 \\
\hline & Difference & $\begin{array}{c}2.5^{*} \\
(0.05\end{array}$ & \\
\hline
\end{tabular}

Note: * significance at the 10\%-level; \# Mann-Whitney test: p-value in parentheses, one-sided test.

Thus, there are a couple of competing hypotheses about people's fairness judgments and perceived entitlements. Our first main result records the evidence.

Result 1. We find a strong entitlement effect in the fairness judgments with the proportional split according to the claims being the empirically predominant focal point. We also observe that the fairness judgments are role-dependent.

Table 2 and Figure 1 show that the average judgment of the fair settlement is strongly skewed away from the equal split towards the proportional split. The average perceived fair share was 62.8 percent. $^{8}$ As Figure 1 shows, only a few people thought that the equal split is the fair settlement in the eyes of an arbitrator; almost all people believed that a fair settlement entitles the winner to more than the equal split. A relative majority of people believed that the fair sharing is a split of the reduced pie in proportion to the claims. A test of proportions confirms that the fraction of people who believed that the proportional split is fair is significantly higher that the share of people who considered the equal split as being fair $(p<0.001$, two-sided). Thus there can be no doubt that our subjects derived a strong entitlement from the sunk claims.

Figure 1 also shows that fewer losers than winners thought that the proportional split is the fair settlement. Though the effect is not large, the results suggest that the fairness judgment is role-dependent (Table 2). On average the winners thought that the fair share to the winner according to the arbitrator question is 64.0 percent, whereas the losers thought that on average the fair share is 61.6 percent. The difference in fairness judgments is weakly significant ( $p=0.078$, two-sided t-test). This roledependent fairness judgments suggest the presence of a self-serving bias (e.g., Babcock et al. [1995]). In section IV we will take up the issue of self-servingly biased fairness judgments and how they might influence negotiations.

\footnotetext{
${ }^{8}$ The fairness judgments do not differ according to gender, age, income, and field of study of the respondents (all $p$-values are at least 0.20 ).
} 


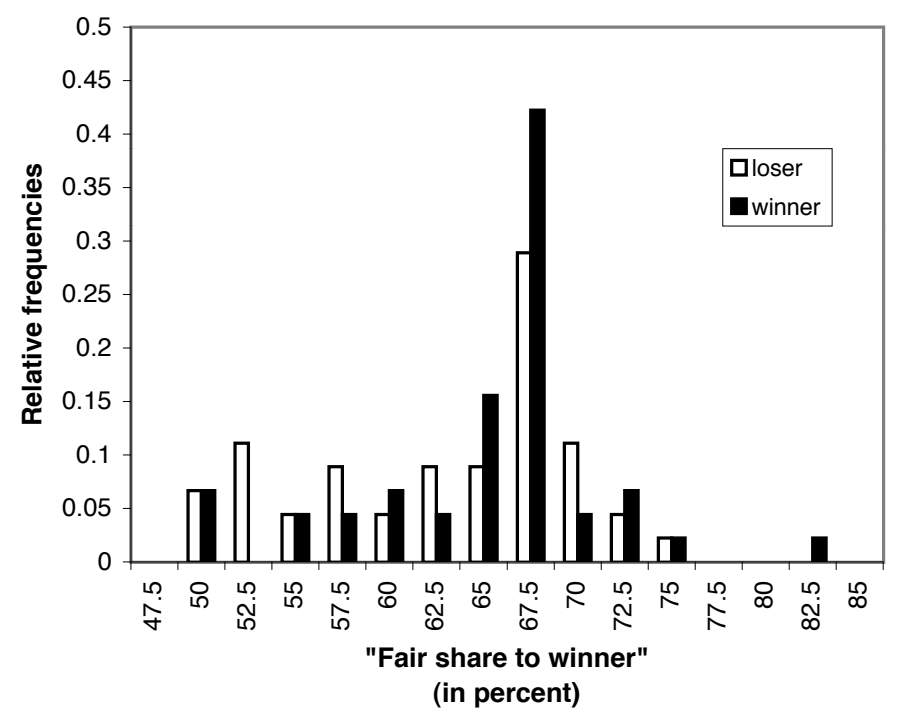

Figure 1. Distribution of Fairness Judgments

\section{B. The Role of Entitlements in the Bargaining Process}

Although it is remarkable that losers thought they are entitled to less than 40 percent, one may object that such fairness judgments are vacuous statements. Moreover, the definitions of entitlements and obligations demand that people have a motivational disposition to defend or respect them. Put differently, entitlement effects in bargaining require that we should find a correlation between the fairness judgments and negotiation behavior. Yet, for at least two reasons finding such correlations is not straightforward. First, it must actually be the case that fairness judgments are more than mere words: finding a correlation requires that negotiators feel committed to their entitlements and express this in their bargaining behavior. Second, entitlements may be mutually inconsistent because they sum up to more than 100 percent. Indeed, of our 45 bargaining pairs, 23 pairs expressed mutually inconsistent entitlements. These negotiators have to compromise on their entitlements if they want to avoid an impasse.

If fairness judgments matter, we expect that they influence the negotiation process as follows: (i) the opening offers of both winners and losers are positively correlated with their respective fairness judgments and (ii) the larger the difference in fairness judgments between losers and winners is, the longer it takes to reach an agreement and the lower are concessions.

Figure 2 and the statistical analysis reported in Tables 4 - 6 in the Appendix provide the support for our second result:

Result 2. Fairness judgments are statistically significantly correlated with (i) opening offers, (ii) bargaining duration, and (iii) concessionary behavior.

We will now discuss the support for results (i) to (iii) in turn.

Opening offers. Figure 2(a) depicts - separately for losers and winners - the opening share to the winner (defined as the very first offer) of a particular subject who has made an opening offer as a function of this subject's fairness judgment. As the 
scatterplot demonstrates and the Spearman rank correlation verifies, there is a highly significantly positive relation between the fairness judgments of losers and the losers' opening shares to the winner. ${ }^{9}$ While losers exhibit a considerable variation in their fairness judgments and opening offers, the fairness judgments of winners who made an opening offer cluster around the proportional split. Accordingly, winners also tended to ask for the proportional split (or more).

Figure 2(a) also shows that the opening offers depended on who was making them (the difference in opening offers between losers and winners is highly significant (twosided Mann-Whitney test; $p<0.01)$ ). The observation that fairness judgments have significantly influenced the opening offers allows us to separate the entitlement effect in the opening offers from a strategic offer effect. On average, winners who made an opening offer thought that a winner share of 66.7 percent is fair and actually asked for 71.6 percent; losers who made an opening offer judged a share of 61.1 percent as fair and offered only 52.4 percent. Thus, the strategic offer effect amounts to 4.9 percent for winners and to 8.8 percent for losers. Both effects are highly significant according to Wilcoxon signed rank tests that compare opening offers and fairness judgments $(p<0.01)$.

Bargaining Duration and Concessionary Behavior. It is natural to look at bargaining duration as a function of the tension in fairness judgments. Figure 2(b) plots the bargaining duration against the difference in fairness judgments between a winner and a loser (i.e., DIFF_FAIR $=$ W_FAIR - L_FAIR). ${ }^{10}$

The figure nicely shows that there is a significantly positive correlation between the tension in fairness judgments in a bargaining dyad, and the bargaining duration (in Figure 2(b) " $\times$ " denote disagreements; they are, however, excluded in the calculation of correlations). We corroborate this observation with several robustness checks in a Tobit regression analysis, which can be found in the Appendix.

On average it took negotiators 590 seconds to reach an agreement. Bargaining pairs with a negative tension in their fairness judgments reached an agreement in 435 seconds, whereas pairs with inconsistent entitlements (i.e., DIFF_FAIR $>0$ ) needed 737 seconds to strike an agreement. The difference is more than five minutes and highly significant according to a Mann-Whitney test ( $p=0.003$, two-sided).

Our findings also shed new light on the often observed "deadline effect" in bargaining [Roth, Murnighan, and Schoumaker, 1988]. As in many related previous bargaining experiments most agreements in our experiment were reached in the very last minute; up to the last minute agreement times are roughly uniformly distributed. These results are similar to those reported by Roth et al. [1988]. Inconsistent fairness judgments were

\footnotetext{
${ }^{9}$ Due to distorting graphical scale effects, Figure 2(a) does not contain the 'outlier' $(50,2.4)$. In the calculation of the Spearman rank correlation coefficient reported in the figure, the outlier is included, however. The positive correlation also holds if we remove the outlier: $\rho=0.47 ; p=0.011$. These findings are also corroborated by a Tobit regression analysis, which can be found in Table 4 in the Appendix.

${ }^{10}$ Note that this measure may become negative if the loser would give more to the winner than the winner according to the arbitrator question. We interpret this as observing no tension in the bargaining dyad. Notice further that a positive difference in fairness judgments is equivalent to having inconsistent entitlements (which sum up to more than 100 percent) whenever the loser grants the winner at least 50 percent of the pie.
} 

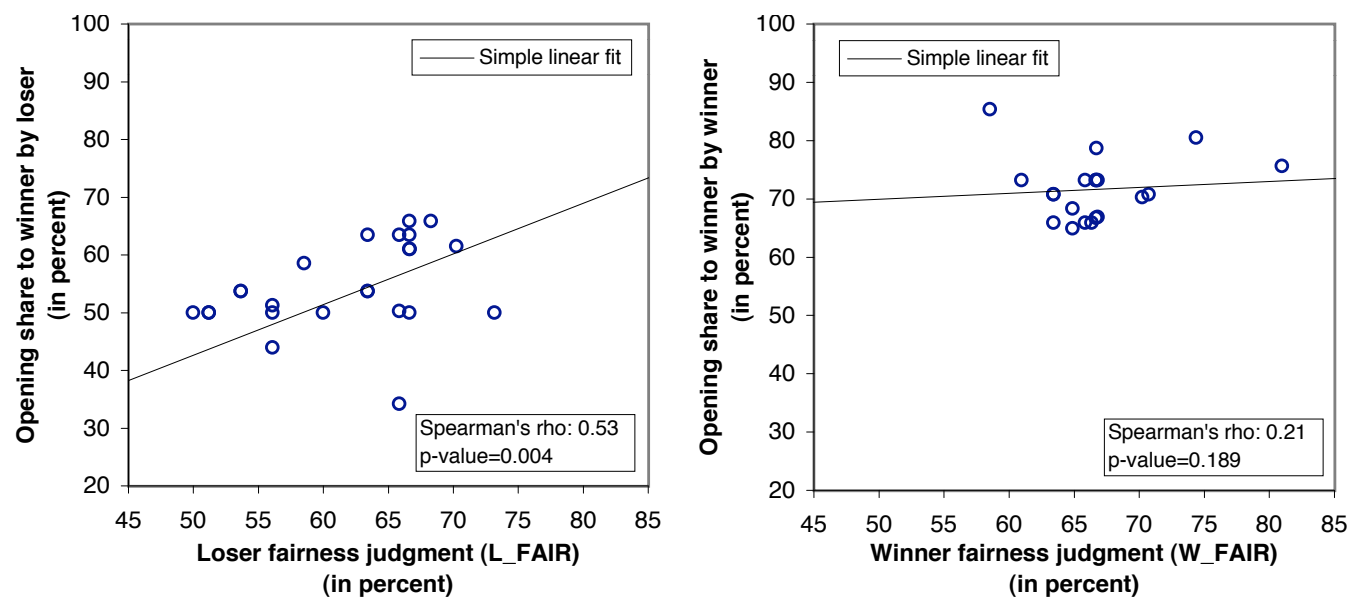

(a) Opening Offers

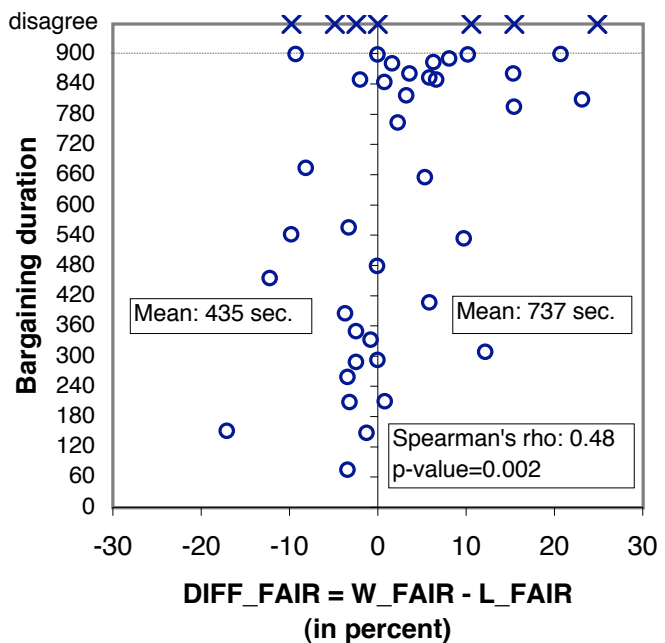

(b) BARgaining Duration

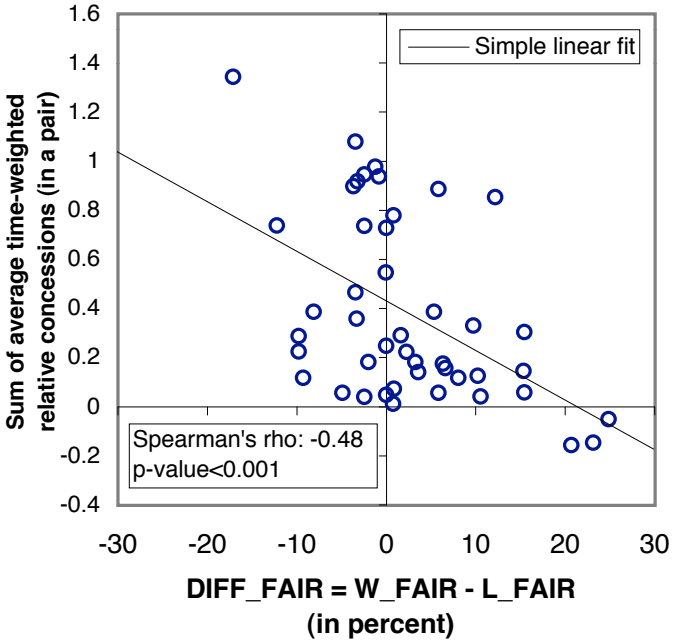

(c) Concession Behavior

\section{Figure 2. Bargaining Behavior is influenced By the Fairness Judgments}

a major determinant of the deadline effect in our experiments. On average, DIFF_FAIR of all pairs who reached an agreement in the very last minute was 5.2 percentage points; the average DIFF_FAIR of agreements prior to the last minute was only 0.3 percentage points. This difference is significant according to a Mann-Whitney test $(p=0.03$, two-sided). ${ }^{11}$

As we have seen, opening offers of losers and winners are on average rather far apart from each other. Thus, concessions are necessary to reach an agreement. We define a

\footnotetext{
${ }^{11}$ Although there may exist strategic reasons to delay the negotiations [Fershtman and Seidman, 1993; Ma and Manove, 1993] our results show that delay is significantly affected by differences in fairness judgments. Thus, tension in entitlements is an independent cause of delay. This also holds if we control for the difference in opening offers (see the regression model in the Appendix).
} 
concession as an offer (measured in the winner share) that makes the opponent better off. However, depending on the 'current bargaining area' - which we define as the difference in standing offers of the two negotiators - the same absolute concession can be large or small (of course, a concession leads to a new and smaller current bargaining area). We therefore normalize concessions by the current bargaining area, which gives us the relative concession as one measure of concessionary behavior. In the following we will investigate three individual statistics of the concessionary behavior of a negotiator: (i) the average relative concession, (ii) the average concession time, i.e., the average point in time a negotiator made a concession, and (iii) the average time-weighted relative concession. ${ }^{12,13}$

We expect that the farther apart the fairness judgments are, the lower will a concession be and/or the later will a concession occur. However, previous research (see, e.g., Kuon and Uhlich [1993]; and Hennig-Schmidt [1999]) suggests that concessionary behavior is to some extent reciprocal, i.e., concessions made by one negotiator also depend on concessions made by the opponent. Thus, between negotiators, concessions and concession times are expected to be correlated. This is indeed the case for all but one statistics. ${ }^{14}$ To cope with the problem of correlated concessions, we restrict our analysis to bargaining pairs by taking for each pair the sum of a particular individual concession statistic as the relevant unit of observation. In statistical terms we expect, therefore, (i) the sum of average relative concessions to be negatively correlated with DIFF_FAIR, (ii) the sum of average concession times to be positively correlated with DIFF_FAIR and (iii) the sum of average time-weighted relative concessions to be negatively correlated with DIFF_FAIR.

The Spearman rank correlations (one-sided tests) support these hypothesis: They are (i) $-0.28(p<0.05)$, (ii) $0.49(p<0.001)$ and (iii) $-0.48(p<0.001)$, respectively. Figure 2(c) illustrates the connection between DIFF_FAIR and concessionary behavior for our most encompassing concession statistics, the sum of average time-weighted

\footnotetext{
${ }^{12}$ The exact definitions are as follows. A relative concession of a winner is defined as the difference between a winner's standing offer (in winner share) and his new offer (in winner share) divided by the current bargaining area. The current bargaining area is given by the difference between the standing offer of the winner (as winner share) and the standing offer of the loser (as winner share). (Note that with this definition concessions can also be negative.) A relative concession of a loser is defined analogously. For example, if the standing offers of a winner and a loser are 0.7 and 0.5 , resp. (i.e., the current bargaining area is 0.2 ), and the winner now demands only 0.6 for himself, then the absolute concession is 0.1 and the relative concession is $0.5(=0.1 / 0.2)$. The initial bargaining area is assumed to be the difference in claims (i.e., $(1660-830) / 2050 \approx 0.4)$. An acceptance is calculated as a relative concession of 1 . The summary statistics average relative concession of a bargainer is just the average of all his relative concessions made during the bargaining process.

The average concession time of a bargainer is defined as the sum of concession times divided by the number of concessions.

A time-weighted relative concession is a relative concession (as defined above) multiplied with (901 - time of concession) if the concession is positive and multiplied with time of concession if the concession is negative, respectively. This measure has the property that a given positive (negative) relative concession gets the less (more) weight the later the concession is made. The statistics we use is the average of all time-weighted relative concessions of a negotiator.

${ }^{13}$ The average relative concession made by a negotiator amounted to 28.9 percent of the respective bargaining area, and the average concession time was 397 seconds. The average time-weighted relative concession was 0.176. Differences between roles are small and insignificant (according to Wilcoxon signed ranks tests).

${ }^{14}$ The Spearman rank correlation coefficients are as follows ${ }^{* * *}$ denotes significance at the 1-percent level; one-sided tests): (i) average relative concession: 0.055 ; (ii) average concession time: $0.767^{* * *}$; and (iii) average time-weighted concession: $0.390^{* * *}$.
} 
relative concessions. All our results are corroborated by regression analyses (see the Appendix).

Thus, the greater the tension with respect to fairness judgments in a bargaining pair the later concessions are made and the smaller concessions are. These findings also provide an explanation why we observe a significant relationship between fairness judgments and bargaining duration.

\section{Entitlements and Agreements}

The ultimate interest in a negotiation is to reach an agreement. In previous symmetric free-form bargaining experiments with zero conflict payoffs almost unanimously an exact equal split of the surplus has been observed (see, e.g., Nydegger and Owen [1975]). If the sunk claims exert any influence, i.e., if there is an entitlement effect in the agreements, the distribution should be skewed away from the equal split. In addition, if the fairness judgments have any influence in shaping the agreements, there should be a correlation of reached agreements with the fairness judgments.

We expect that in a pair the agreed share to the winner is positively correlated with the fairness judgments of a winner and the fairness judgment of a loser. The rationale for this hypothesis is that the more any of the bargainers in a pair would give to the winner according to the arbitrator question, the 'easier' it should be to actually agree on a higher winner share. Our third main result establishes both the entitlement effect and the influence of the fairness judgments in shaping the agreements.

Result 3. (i) We find a strong entitlement effect in the agreements: On average the agreed share to the winner is 60.5 percent. (ii) The fairness judgments of winners and losers are highly significantly positively correlated with the agreements. (iii) Our results suggest that disagreements are indirectly related to the fairness judgments.

Figure 3 provides graphical support for our results 3(i) and 3(ii). Figure 3(a) shows the distribution of agreements in the experiment. It provides strong evidence for an entitlement effect in the reached agreements. The distribution of agreements is highly significantly skewed away from the equal split $(t=9.6)$. Only 11 percent of the agreements implemented the equal split. The most common agreements occurred at 67 percent, i.e., the proportional split according to the claims. We even observe agreements above the proportional split. The mean agreed share to the winner was 60.5 percent. $^{15}$

\footnotetext{
${ }^{15}$ One objection against the interpretation that the observed distribution of agreements reflects an entitlement effect may be that the winners are just smarter bargainers. For at least three reasons, we consider this to be very unlikely. First, in symmetric bargaining games unanimous equal splits are observed. If smartness would matter we should also observe some variance in these symmetric bargaining games, which we don't. Second, if smartness plays a role there should be some correlation between the number of correct answers in the quiz and his/her bargaining tactics as revealed in concession behavior. We do not find significant correlations between the number of correct answers and our concession statistics. Third, if it is the winners' smartness that drives the agreements then we should find a positive (negative) correlation between the number of correct answers of winners (losers) or the difference in correct answers between winners and losers with the agreed winner share. This is not the case. The $p$-values of the Spearman rank order correlation statistics are never below 0.37 (two-sided tests).
} 


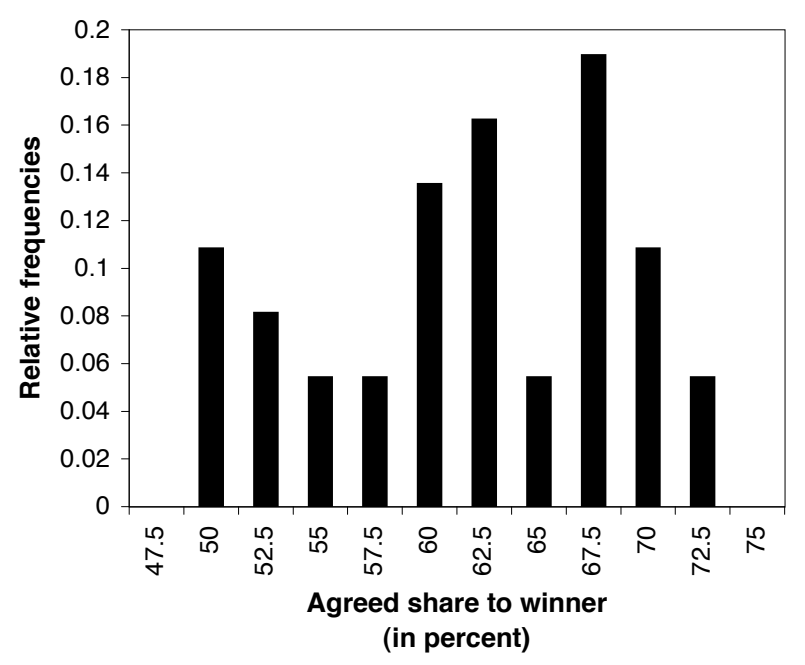

(a) Distribution of Agreements
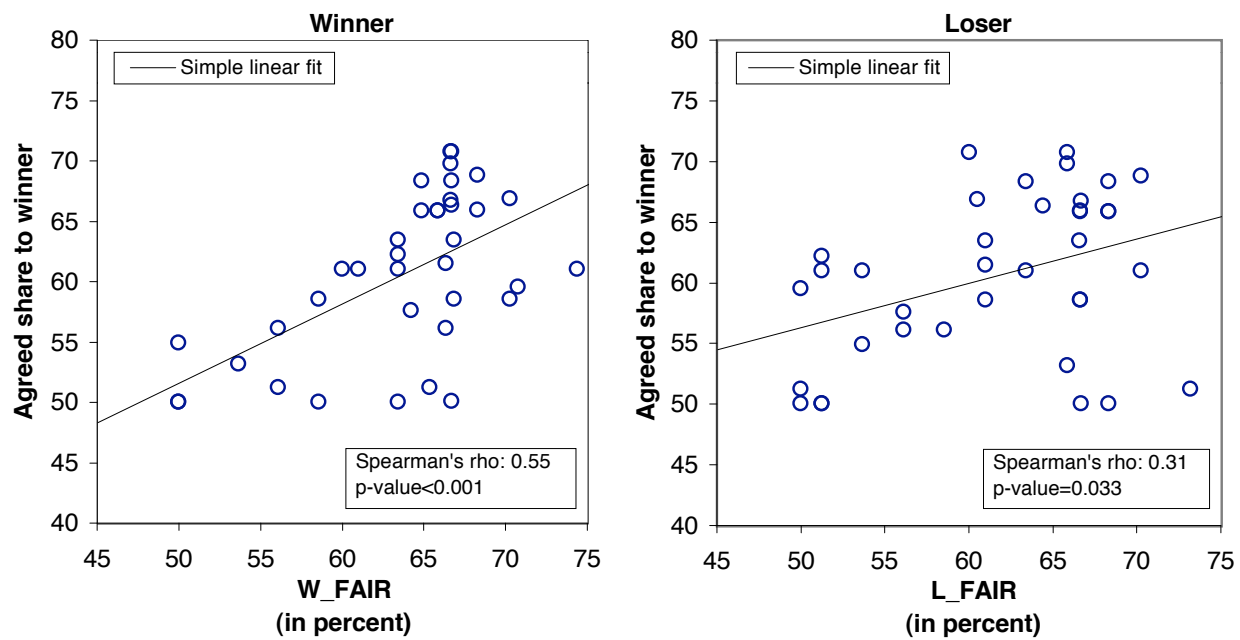

(b) Agreements are influenced By the Fairness Judgments

\section{Figure 3. Agreements}

Figure 3(b) depicts the correlation of reached agreements and the fairness judgments. The results are consistent with all our previous observations. We find a strongly positive correlation between fairness judgments of winners and losers and the agreed share to the winner. The Spearman rank correlation between the fairness judgment of a winner and the reached agreement is positive and highly significant $(\rho=0.55, p<0.01$, one-sided test); for the loser it is as well significantly positive $(\rho=0.31, p=0.033$, onesided test). This clearly supports our hypothesis. The robust Tobit estimates that are reported in Table 7 of the Appendix strengthen these findings. There the coefficients of W_FAIR and L_FAIR are both positively significant at the 1 percent level (two-sided tests). Thus, fairness judgments not only significantly shape the bargaining process, but agreements as well. 
Evidence for the importance of entitlements also comes from the messages that could be sent along with proposals. From the total of 406 proposals 287 were accompanied by some message. Seventy of them contained text with arguments referring to fairness considerations and/or entitlements and obligations. Forty-two of these messages were sent by winners and 28 by losers. In 33 cases winners argued for unequal divisions near the proportional split because of better performance and performance-based fairness considerations. Interestingly, in almost fifty percent of the cases (13 out of 28) losers also argued along these lines. (Though their proposed winner share was mostly smaller than the winner share demanded by the winner.) The other half of the classified loser messages contained arguments for the equal split (i.e. fairness considerations not related to performance). In contrast, only four of the 33 messages of winners contained such arguments. In our view, this supports the conclusion that winners' bargaining behavior was strongly influenced by entitlements derived from the sunk claims. Furthermore, it seems that a non-negligible part of losers actually felt obliged to concede the winners significantly more than half of the pie.

The results of our second experiment (see Table 1 also support the importance of entitlements and obligations. This experiment was the same as the first one except that new pairs were formed and that we did not ask the arbitrator question. Naturally, some of the winners (losers) in the first experiment became losers (winners) in the second experiment, whereas some were in the same role in both experiments. We find that subjects made significantly different opening offers in the first and the second experiment if their roles were different in the two experiments. Subjects who were winners (losers) in the first experiment but losers (winners) in the second experiment significantly decreased (increased) their opening offers. Subjects with the same role in both experiments did not change their opening offers. Thus, entitlements (only) changed with an alteration in roles. The average winner share in the agreements is with 59 percent of the pie within keeping to the results of the first experiment. This underscores the robustness of our findings with respect to role changes and experience.

A major enigma for any economic bargaining theory is the explanation of disagreements. In our experiment we observed a total of 7 disagreements (16 percent of all bargaining encounters). Although the percentage of disagreements is completely in line with previous findings (see Roth et al. [1988]), in absolute terms they are still a few cases. We can therefore only sketch possible determinants of disagreements.

In accord with our previous analyses we expect that disagreements are characterized by larger differences in fairness judgments than agreements. Indeed the difference in fairness judgments is lower for agreements than for disagreements ( 2 and 4.8 percent, resp.). Yet, according to a Mann-Whitney test this difference is not significant ( $p=0.380$, one-sided test). Thus, in our data we cannot detect a direct influence of the differences in fairness judgments on the disagreements (see also Figure 2(b)). However, a further analysis shows that (i) the difference in first offers and the average concession time are significantly lower for agreements than for disagreements, whereas (ii) the average relative concession, and the average time-weighted relative concession are significantly larger for agreements than for disagreements. ${ }^{16}$ Yet, as we have seen in the

\footnotetext{
${ }^{16}$ The difference in first offers of winner shares of pairs who reached an agreement (failed to reach an agreement) was 13.7 percentage points (27.6 percentage points). The difference is highly significant according to a Mann-Whitney test $(p=0.003$, one-sided). Moreover, according to all our three concession statistics, pairs who ended up in an impasse exhibited highly significantly less concessionary
} 
previous subsections both opening offers and concessionary behavior are significantly influenced by the fairness judgments. Hence, indirectly, the fairness judgments seem to have influenced the settlement rates.

Did the entitlements actually pay off, given that they might have led to bargaining impasse and zero payoffs? A calculation of Spearman rank order correlations between final payoffs (including the conflict payoffs of zero in case of disagreements) and the fairness judgment reveals a significantly positive correlation of the winners' final payoff with their fairness judgments ( $\rho=0.33 ; p=0.014$, one-sided). For losers the correlation between the final payoff and fairness judgments is weakly significantly negative $(\rho=$ $-0.204 ; p=0.092$, one-sided). Thus, in our experiments entitlements did pay off especially for winners.

\section{The Role of the Self-Serving Bias in the Entitlements}

Entitlements and obligations by negotiators are grounded in what they perceive as being a 'fair' agreement. However, by now there is considerable evidence that fairness judgments may be self-servingly biased. In accordance with Dahl and Ransom [1999, p. 703] we define a self-serving bias in fairness judgments as follows: "A self-serving bias occurs when individuals subconsciously alter their fundamental views about what is fair or right in a way that benefits their interest." Evidence for such a self-serving bias has been produced in tightly controlled laboratory experiments [Messick and Sentis, 1979; Thompson and Loewenstein, 1979; Loewenstein, Issacharoff, Camerer, and Babcock, 1993; Camerer and Loewenstein, 1993; Babcock et al., 1995; Konow, 2000] but also in field studies [Babcock, Wang, and Loewenstein, 1996] and in survey studies [Dahl and Ransom, 1999]. ${ }^{17}$

In our experiment the fairness judgments of losers were lower than those of the winners, which suggests the existence of a self-serving bias among our bargainers (see Table 2). However, the difference is small in magnitude and only weakly significant. We find this to be a surprising result, given (i) the findings of previous research, (ii) the existence of possible multiple focal points of our bargaining problem, and (iii) the presence of a self-serving bias in ability judgments among our subjects (see also Camerer and Loewenstein [1993] and Babcock and Loewenstein [1997]). It seems that the perceived entitlements and obligations in our bargaining with claims experiment were strong and unambiguous enough to diminish a self-serving bias. This holds especially for the losers who largely did not think that the equal split is fair.

Although the self-serving bias in our experiment was rather small, it may nevertheless have influenced the fairness judgments, and hence the negotiations. This raises the question to what extent unbiased fairness judgments, made behind the "veil of ignorance", influence negotiations. To test this, we ran a control condition with another 22

\footnotetext{
behavior than those pairs that were willing to compromise (all $p$-values $<0.001$, one-sided).

${ }^{17}$ The presence of a self-serving bias is not restricted to fairness judgments. It is a well-known phenomenon that over 50 percent of survey respondents view themselves as above-average drivers [Svenson, 1981], a finding which we have reproduced by asking our subjects in the post-experimental questionnaire to self-assess their general knowledge (even the losers of the knowledge quiz judged themselves to be above average in general knowledge!). Likewise, as we have discussed above, people (including our subjects) tend to attribute their successes to their ability and failures to bad luck [Zuckerman, 1979]. See Babcock and Loewenstein [1997] for a survey of the most important findings.
} 
bargaining pairs. The control experiments were exactly the same as the experiments of our main condition with one important difference. In the control condition subjects had to answer the arbitrator question before they knew whether they will be the winner or the loser of the performance quiz. Actually, the arbitrator question was asked right after reading the instructions and before performing the knowledge quiz (this procedure is adapted from Babcock et al. [1995]). In this setting fairness judgments can by definition not be self-servingly biased. ${ }^{18}$ We summarize the findings of this control experiment in the following

Result 4. If subjects assess fairness before they know their role in the negotiations, the fairness judgments of ex post winners and losers do not differ. Furthermore, in contrast to our main condition, the fairness judgments made 'behind the veil of ignorance' cannot explain the variation in bargaining behavior in any phase of the negotiations. The average bargaining behavior is similar as in our main condition.

Table 3 provides the support for the results of the control condition. It documents the Spearman rank order correlations for each of our bargaining statistics with the relevant fairness judgment measures (see also the note at the bottom of the table). For the sake of comparisons, this table also summarizes the means (and standard deviations) of the main condition, as well as the control condition. In the last column we report the $p$-values of statistical comparisons of the main condition with the control condition.

The most important findings are as follows. First, as expected, fairness judgments of ex post winners and losers are virtually the same $(p=0.804$, two-sided Mann-Whitney test) and lie between the fairness judgments of winners and losers in our main condition. Second, in stark contrast to our main condition, fairness judgments made behind the "veil of ignorance" do not explain the variation in bargaining behavior (see column 'Correlation' of Table 3). Not a single correlation of a particular bargaining statistics with the respective fairness judgment is significant at the conventional levels. Third, there are no treatment differences between the levels of our variables of bargaining behavior in our main condition and the control condition. The only possible exception is bargaining duration, which was weakly significantly longer in the control condition than in the main condition.

The agreements are of particular interest. As in our main condition we also find a strong entitlement effect in our control condition. The mean agreed share to the winner is 62.3 percent and not significantly different from the 60.5 percent observed in our main condition ( $p=0.495$, two-sided Mann-Whitney test). Although there is no correlation between the variation in fairness judgments and the variance of the reached agreements, notice that the levels of agreement and fairness judgments correspond closely.

\footnotetext{
${ }^{18}$ One may object that even in this condition subjects may have formed beliefs about their likely claim as the outcome of the quiz, because they have some idea about their performance in such a quiz. If this guess is correct they may have 'anticipated' their claim and, therefore, their fairness assessment may also have been influenced by a self-serving bias. We consider this to be very unlikely. First, the actual difference in the number of correct answers between losers and winners is small (2.7 on average). Second, as shown below, the difference in fairness judgments is virtually non-existent. Third, when answering the arbitrator question subjects only knew that their claim will be determined according to their answers to 16 questions from very different fields, but they did not know the 16 questions. However, to test the objection, we correlated the number of correct answers to the answers in the fairness judgments. We do not find any significant correlation. This also holds if we only consider the best and worst performers in the quiz, respectively.
} 
TABle 3 - Summary StATistics AND CORRELATIONS With FAIRNESS JUDGMENT (MAIN CONDITION AND CONTROL CONDITION)

\begin{tabular}{|c|c|c|c|c|c|c|}
\hline & \multicolumn{2}{|c|}{ Main condition } & \multicolumn{3}{|c|}{ Control condition } & \multirow{2}{*}{$\begin{array}{c}\text { Comparison of } \\
\text { main and contro } \\
\text { condition } \\
\text { p-values }\end{array}$} \\
\hline & $\begin{array}{c}\text { Mean } \\
\text { (Std. dev.) }\end{array}$ & $\mathrm{N}$ & $\begin{array}{c}\text { Mean } \\
\text { (Std. dev.) }\end{array}$ & $\mathrm{N}$ & Correlation & \\
\hline \multicolumn{7}{|c|}{ Fairness judgments (in percent) } \\
\hline Winner & $\begin{array}{r}64.0 \\
(6.2)\end{array}$ & 45 & $\begin{array}{l}61.8 \\
(7.1)\end{array}$ & 22 & & $0.287^{d}$ \\
\hline Loser & $\begin{array}{l}61.6 \\
(6.8)\end{array}$ & 45 & $\begin{array}{r}62.3 \\
(6.6)\end{array}$ & 22 & & $0.634^{d}$ \\
\hline \multicolumn{7}{|c|}{ Opening offers (in percent) } \\
\hline Winner & $\begin{array}{r}71.6 \\
(5.4)\end{array}$ & 20 & $\begin{array}{c}70.8 \\
(10.5)\end{array}$ & 12 & $-0.21^{a}$ & $0.327^{d}$ \\
\hline Loser & $\begin{array}{c}52.4 \\
(12.8)\end{array}$ & 25 & $\begin{array}{l}54.3 \\
(4.4)\end{array}$ & 10 & $0.00^{b}$ & $0.970^{d}$ \\
\hline $\begin{array}{l}\text { Bargaining duration } \\
\text { (in seconds) }\end{array}$ & $\begin{array}{c}590 \\
(278)\end{array}$ & 37 & $\begin{array}{l}718 \\
(228)\end{array}$ & 17 & $0.30^{c}$ & $0.061^{d}$ \\
\hline $\begin{array}{l}\text { Sum of average } \\
\text { relative concessions }\end{array}$ & $\begin{array}{c}0.614 \\
(0.452)\end{array}$ & 44 & $\begin{array}{c}0.537 \\
(0.388)\end{array}$ & 22 & $-0.14^{c}$ & $0.496^{d}$ \\
\hline concession times & $\begin{array}{c}767 \\
(336)\end{array}$ & 44 & $\begin{array}{c}872 \\
(251)\end{array}$ & 22 & $0.07^{c}$ & $0.237^{d}$ \\
\hline $\begin{array}{l}\text { time-weighted } \\
\text { relative concessions }\end{array}$ & $\begin{array}{c}0.389 \\
(0.377)\end{array}$ & 44 & $\begin{array}{c}0.286 \\
(0.336)\end{array}$ & 22 & $-0.10^{c}$ & $0.334^{d}$ \\
\hline $\begin{array}{l}\text { Agreements } \\
\text { (in percent) }\end{array}$ & $\begin{array}{l}60.5 \\
(6.7)\end{array}$ & 37 & $\begin{array}{l}62.3 \\
(4.2)\end{array}$ & $\begin{array}{l}17 \\
17\end{array}$ & $\begin{array}{r}-0.29^{a} \\
0.32^{b}\end{array}$ & $0.495^{d}$ \\
\hline $\begin{array}{l}\text { Disagreement rate } \\
\text { (in percent) }\end{array}$ & 15.9 & 44 & 22.7 & 22 & & $0.515^{e}$ \\
\hline \multicolumn{7}{|c|}{ Final payoffs (in percent) } \\
\hline Winner & $\begin{array}{c}50.9 \\
(23.2)\end{array}$ & 44 & $\begin{array}{c}48.1 \\
(27.0)\end{array}$ & 22 & $-0.00^{a}$ & $0.962^{d}$ \\
\hline Loser & $\begin{array}{c}33.2 \\
(15.8)\end{array}$ & 44 & $\begin{array}{c}29.1 \\
(16.6)\end{array}$ & 22 & $0.05^{b}$ & $0.342^{d}$ \\
\hline
\end{tabular}

How can we reconcile the puzzling observations of Results 2 to 4 that (i) with role knowledge fairness judgments and negotiation behavior are highly significantly correlated; that (ii) the entitlements assessed behind the veil of ignorance cannot explain the variation in bargaining behavior; and that (iii) the mean negotiation behavior in our control experiment is not statistically significantly different from the main experiment? We suggest the following speculative argument. It is inspired from research on the 'hot-cold empathy gap' which is a pervasive phenomenon in decision-making (see, e.g., Loewenstein [2000]). Being in the 'hot state' of knowing one's economic position when making a fairness judgment may lead to a (subconscious) commitment to the stated fairness assessments. This commitment may be reinforced by a self-serving bias. 
Feelings of commitment to (biased) fairness judgments are likely to shape behavior. This explains Results 2 and 3. In our control condition negotiators made their fairness judgments in the 'cold state' of not yet knowing their role. The 'cold' fairness judgments may have led to an insufficiently strong commitment to influence bargaining behavior. Once bargainers learned their claims and moved into the 'hot state', some of them may have reassessed their fairness judgments and gotten committed by them in a similar way as the subjects of our main condition. This would explain Result 4 .

We conclude this section with two related observations on the link between expressed entitlements and behavior. First, in reality bargainers usually know their economic position. For this case, our results suggest that the negotiators' expressed entitlements are not only used for strategic purposes but bear a close relationship to what negotiators believe and actually do. Thus, as argued by several authors before us (see, e.g., Elster [1989]; Zajac [1995]; Konow [2000]) fairness is not just a smoke-screen to advance selfinterest. This can most clearly be seen from the losers' negotiation behavior, which largely reflects their expressed obligations (see Figures 2(a) and 3(b)). ${ }^{19}$

The second observation is more methodological and points to the usefulness of eliciting subjective data. Economists are often sceptical towards measuring "subjective verbal statements" without any direct economic consequence, of which our elicited fairness judgment is an example. We find that the knowledge of one's economic position matters for observing a correlation of expressed fairness judgments and observed behavior (the levels of fairness judgment and agreements, for instance, correspond closely regardless of role knowledge). Again, since in reality people usually know their position, our results suggest that despite a possible self-serving bias, the expressed subjective fairness judgments are likely to be meaningful in that they correspond to observed behavior. $^{20}$

\section{Discussion and Conclusions}

There can be no doubt that subjects in our experiments derived a 'moral property right' from the claims they have earned. By letting subjects negotiate in a situation where they experienced sunk claims, we created a testbed for studying entitlements and obligations in the sense of Schlicht's definition given in the Introduction. The claims were sunk and yet they instilled in our subjects a subjectively perceived right or obligation. This is reflected in the fairness judgments. Moreover, as the negotiation behavior shows, subjects with the high claim ('winners') were willing to defend their moral property rights and subjects with the low claim ('losers') largely felt obliged to accept them.

\footnotetext{
${ }^{19}$ Our observations may also shed light on the results of Boeri et al. [2001], who conducted a large survey on attitudes of European citizens on welfare state reforms. They find that a majority is content with the status quo. Yet, people's take on the status quo (e.g., with respect to pension reforms) largely depends on their economic interest (e.g., young vs. old), which is a source of potential political conflict. These survey observations are consistent with our findings. Our results on the connection between entitlements and bargaining behavior suggests that tensions in entitlements will significantly influence negotiations on welfare state reforms.

${ }^{20}$ Glaeser, Laibson, Scheinkman and Soutter [2000] come to an analogous conclusion in a study that measures trust with survey questions and experiments.
} 
To put our results into perspective it is instructive to compare them to previous research on entitlements. Most previous research investigated entitlement effects in simple asymmetric one-shot games, like ultimatum and dictator games. Moreover, only a few studies elicited the perceived entitlements and linked them to bargaining behavior. ${ }^{21}$ In most studies, any entitlement effect was just inferred from the observed behavior. For instance, in an early study, Hoffman and Spitzer [1985] systematically investigated the role of being entitled to be 'the controller', who had the sole right to make one allocation decision in a dictator game. They find that the controllers' behavior is more selfish when he earned the right to be the controller than when he was randomly assigned to be the controller (see also Burrows and Loomes [1994] and Harrison and McKee [1985]). Hoffman, McCabe, Shachat and Smith [1994] get similar results in ultimatum and dictator games. Likewise, in contrast to experiments with random role assignments Güth and Tietz [1985] find no equal splits anymore in the ultimatum game when roles are auctioned off. ${ }^{22}$

A comparison of the previous findings with our results suggests an interesting relation between 'legal' and 'moral' property rights. Legal property rights are crucial for the usual Coasean reasons (for experimental evidence see e.g., Harrison and McKee [1985]; Hoffman and Spitzer [1985]; Croson and Johnston [2000]). In the above-mentioned experiments the 'legal property rights' granted the players certain decision-making powers. The way they were allocated (earned or randomly assigned) changed the entitlement of the strategic powers inherent in the legal property rights of the decision makers. Since in our experiments the 'legal property rights' deliberately put both bargainers in strategically the same position, our results show that this changed perception is only one aspect of entitlements in negotiations. Entitlements constitute a moral property right that also exists irrespective of the legal property rights. Our experiments demonstrate this for the case of claims acquired prior to the negotiations. These results are important for at least two reasons. First, as the introductory examples demonstrate and as authors like Zajac [1995] and Schlicht [1998] have forcefully argued, in many cases the history of transactions and the status quo strongly shape negotiators' moral property rights. Second, our results have demonstrated the link between entitlements and bargaining behavior. Our findings suggest, therefore, that bargainers in addition to their legal property rights will put their moral ones as well on the bargaining table.

\footnotetext{
${ }^{21}$ Babcock et al. [1995], whose procedure we have adapted in our elicitation of fairness judgments use the fairness judgments to test for a self-serving bias and to see to what extent the self-serving bias leads to bargaining impasse. Binmore, Morgan, Shaked and Sutton [1991] asked subjects after the experiments what they thought is fair and linked it to the results of the experiment. They find a close correspondence between what people consider as fair and what is strategically optimal for them.

${ }^{22}$ Further experiments on entitlements comprise Frey and Bohnet [1995], Ball and Eckel [1998] and Ruffle [1998] who also manipulated the way in which roles in an ultimatum game or dictator game experiment were determined. Entitlement effects have also been observed in "real effort experiments", in which a real effort task - like doing a concentration test [Mikula, 1972], proof reading [Frohlich and Oppenheimer, 1992], cracking walnuts [Fahr and Irlenbusch, 2000], solving a computerized game of skill [Rutström and Williams, 2000], preparing letters for mailing [Konow, 2000] or solving a twovariable optimization problem [Bosman and van Winden, 2002] — preceded an allocation task. Frohlich and Oppenheimer [1992] were also among the first to study distributive principles 'behind the veil of ignorance'. Entitlement effects are not restricted to bargaining. They can also be observed in markets (see Ball, Eckel, Grossman and Zame [2001]).
} 


\section{References}

Babcock, Linda, and Loewenstein, George (1997). "Explaining bargaining impasse: The role of self-serving biases." Journal of Economic Perspectives, 11(1), pp. 109-126.

Babcock, Linda; Loewenstein, George, Issacharoff Samuel, and Camerer, Colin (1995). "Biased Judgments of Fairness in Bargaining." American Economic Review, 85(5), pp. 1337-1343.

Babcock, Linda; Wang, Xianghong, and Loewenstein, George (1996). "Choosing the wrong pond: Social comparisons in negotiations that reflect a self-serving bias." Quarterly Journal of Economics, CXI(1), pp. 1-19.

Ball, Sheryl and Eckel, Catherine (1998). "The Economic Value of Status." Journal of Socio-Economics, 27(4), pp. 495-514.

Ball, Sheryl; Eckel, Catherine and Zame, William (2001). "Status in Markets." Quarterly Journal of Economics, CXVI(1), pp. 161-188.

Bazerman, Max H. (1985). "Norms of Distributive Justice in Interest Arbitration." Industrial and Labor Relations Review, 38(4), pp. 558-570.

Binmore, Ken; Morgan, Peter, Shaked, Avner and Sutton, John (1991). "Do People Exploit Their Bargaining Power? An Experimental Study." Games and Economic Behavior, 3, pp. 295-322.

Boeri, Tito, Börsch-Supan, Axel and Tabellini, Guido (2001). "Would you like to shrink the welfare state? A survey of European citizens." Economic Policy 32 , pp. $7-50$.

Bosman, Ronald and van Winden, Frans (2002). "Emotional hazard in a powerto-take game experiment." Economic Journal 112(1), pp. 147-169.

Brandel, Franz (1998), "Rabbit: Version 1.0", Mimeo, Institute for Advanced Studies, Vienna.

Burrows, Paul and Loomes, Graham (1994). "The Impact of Fairness on Bargaining Behavior." Empirical Economics, 19, pp. 201-221.

Camerer, Colin (forthcoming). Behavioral Game Theory. Experiments on Strategic Interaction. Princeton: Princeton University Press.

Camerer, Colin and Loewenstein, George (1993). "Information, fairness, and efficiency in bargaining," in Barbara A. Mellers and Jonathan Baron, eds., Psychological perspectives on justice. Theory and applications, Cambridge: Cambridge University Press, pp. 155-179.

Chun, Youngsub and Thomson, William (1992). "Bargaining Problems with Claims." Mathematical Social Sciences, 24, pp. 19-33.

Clark, Jeremy (1998). "Fairness in public good provision: an investigation of preferences for equality and proportionality." Canadian Journal of Economics, 31(3), pp. 708-729. 
Croson, Rachel and Johnston, Jason Scott (2000). "Experimental Results on Bargaining Under Alternative Property Rights Regimes." Journal of Law, Economics and Organization, 16(1), pp. 50-73.

Dahl, Gordon B. and Ransom, Michael R. (1999). "Does Where You Stand Depend on Where You Sit? Tithing Donations and Self-Serving Beliefs." American Economic Review, 89(4), pp. 703-727.

Elster, Jon (1989). The cement of society. A study of social order. Cambridge: Cambridge University Press.

Fahr, René and Irlenbusch, Bernd (2000). "Fairness as a constraint on trust in reciprocity: earned property rights in a reciprocal exchange experiment." Economics Letters, 66, pp. 275-282.

Feith, Douglas J. (1993). "A Mandate for Israel." The National Interest, Fall, pp. 43-58.

Fershtman, Chaim and Seidmann, Daniel J. (1993). "Deadline Effects and Inefficient Delay in Bargaining with Endogenous Commitment." Journal of Economic Theory, 66, pp. 306-321.

Frey, Bruno S. and Bohnet, Iris (1995). "Institutions Affect Fairness: Experimental Investigations." Journal of Institutional and Theoretical Economics, 151/2, pp. 286-303.

Frohlich, Norman and Oppenheimer, Joe A. (1992). Choosing Justice. An Experimental Approach to Ethical Theory. Berkeley: University of California Press.

Glaeser, Edward; Laibson, David, Scheinkman José, and Soutter, Christine (2000). "Measuring Trust." Quarterly Journal of Economics, CXV(3), pp. 811846.

Güth, Werner and Tietz, Reinhard (1985). "Strategic power versus distributive justice - An experimental analysis of ultimatum bargaining", in: Hermann Brandstätter and Erich Kirchler (eds.), Economic Psychology. Linz: Rudolf Trauner Verlag.

Harrison, Glenn and McKee, Michael (1985). "Experimental evaluations of the Coase Theorem", Journal of Law and Economics, 28, pp. 653-670.

Hennig-Schmidt, Heike (1999). Bargaining in a Video Experiment. Determinants of Boundedly Rational Behavior. Berlin: Springer.

Hicks, John (1974). The Crisis in Keynesian Economics. Oxford: Basil Blackwell.

Hoffman, Elizabeth and Spitzer, Matthew L. (1985). "Entitlements, Rights, and Fairness: An Experimental Examination of Subjects' Concepts of Distributive Justice." Journal of Legal Studies, 14, pp. 259-279.

Hoffman, Elizabeth; McCabe, Kevin, Shachat, Keith, and Smith, Vernon (1994). "Preferences, Property Rights, and Anonymity in Bargaining Games." Games and Economic Behavior, 7, pp. 346-380. 
Kahneman, Daniel; Knetsch, Jack, and Thaler, Richard (1986). "Fairness as a Constraint on Profit Seeking: Entitlements in the Market." American Economic Review, 76(4), pp. 728-741.

Konow, James (1996). "A positive theory of economic fairness." Journal of Economic Behavior and Organization, 31(1), pp. 13-35.

Konow, James (2000). "Fair shares: Accountability and cognitive dissonance in allocation decisions." American Economic Review, 90(4), pp. 1072-1091.

Konow, James (2001). "Fair and square: the four sides of distributive justice." Journal of Economic Behavior and Organization, 46(24), pp. 137-164.

Kuon, Bettina, and Uhlich, Gerald R. (1993). "The Negotiation Agreement Area: An Experimental Analysis of Two-Person Characteristic Function Games." Group Decision and Negotiation, 2, pp. 323-345.

Lindbeck, Assar (1995). "Welfare State Disincentives with Endogenous Habits and Norms." Scandinavian Journal of Economics 97(4), pp. 477-494.

Loewenstein, George; Issacharoff, Samuel, Camerer, Colin and Babcock, Linda (1993). "Self-Serving Assessments of Fairness and Pretrial Bargaining." Journal of Legal Studies, XXII, pp. 135-159.

Loewenstein, George (2000). "Emotions in Economic Theory and Economic Behavior." American Economic Review, 90(2), pp. 426-432.

Ma, Ching-to Albert and Manove, Michael (1993). "Bargaining with Deadlines and Imperfect Player Control." Econometrica 61(6), pp. 1313-1339.

Messick, David M. and Sentis, Keith P. (1979). "Fairness and Preference." Journal of Experimental Social Psychology, 15, pp. 418-434.

Mikula, Gerold (1972). "Gewinnaufteilungsverhalten in Dyaden bei variiertem Leistungsverhältnis." Zeitschrift für Sozialpsychologie, 3, pp. 126-133.

Nash, John F. (1950). "The Bargaining Problem.", Econometrica, 18, pp. 155-162.

Nydegger, Rudy V. and Owen, Guillermo (1975). "Two person bargaining: An experimental test of the Nash axioms." International Journal of Game Theory, 3, pp. 239-249.

O'Neill, Barry (1982). "A Problem of Rights Arbitration from the Talmud." Mathematical Social Sciences, 2, pp. 345-371.

Ortmann, Andreas and Gigerenzer, Gerd (1997). "Reasoning in Economics and Psychology: Why Social Context Matters." Journal of Institutional and Theoretical Economics (JITE), 153(4), pp. 700-710.

Romer, Paul M. (1996). "Preferences, Promises, and the Politics of Entitlement", in: Victor Fuchs (ed.): Individual and Social Responsibility - Child Care, Education, Medical Care, and Long-Term Care in America. Chicago: Chicago University Press 1996. 
Roth, Alvin E. and Murnighan, J. Keith (1982). "The Role of Information in Bargaining: An Experimental Study." Econometrica, 50(5), pp. 1123-1142.

Roth, Alvin E.; Murnighan, J. Keith, and Schoumaker, Françoise (1988). "The Deadline Effect in Bargaining: Some Experimental Evidence." American Economic Review, 78(4), pp. 155-162.

Ruffle, Bradley J. (1998). "More Is Better, But Fair Is Fair: Tipping in Dictator and Ultimatum Games." Games and Economic Behavior, 23, pp. 247-265.

Rutström Elisabet E. and Williams, Melonie B. (2000). "Entitlements and fairness: An experimental study of distributive preferences." Journal of Economic Behavior and Organization, 43, pp. 75-89.

Schlicht, Ekkehart. (1998). On Custom in the Economy. Oxford: Clarendon Press.

Selten, Reinhard (1978). "The Equity Principle in Economic Behavior," in Hans Gottinger and Wolfgang Leinfellner (eds.): Decision theory and social ethics. Issues in social choice. Dordrecht: Reidel Publishing.

Svenson, Ola (1981). "Are we all less risky and more skillful than our fellow drivers?" Acta Psychologica, 47, pp. 143-148.

Thompson, Leigh, and Loewenstein, George (1992). "Egocentric Interpretations of Fairness and Interpersonal Conflict." Organizational Behavior and Human Decision Processes, 51, pp. 176-197.

Thomson, William (1995). "Axiomatic Analyses of Bankruptcy and Taxation Problems: A Survey". Rochester Center for Economic Research Working Paper No. 413.

Zajac, Edward E. (1995). Political Economy of Fairness. Cambridge, Mass.: The MIT Press.

Zuckerman, Miron (1979). "Attribution of success and failure revisited, or: The motivational bias is alive and well in attribution theory." Journal of Personality, 47, pp. $245-287$. 


\section{Appendix}

Here we provide robustness tests with the help of robust Tobit regressions for our results presented in subsections III.B to III.C. We proceed in the same sequence as in the main text by reporting first the results concerning the bargaining process, i.e. opening offers, bargaining duration and concessions, followed by the results concerning the agreements. The regression results confirm the results stated in the main text.

Opening offers. The results reported in Table 4 confirm those provided in the main text (see Result 2 (i)). Like the Spearman rank order correlations the regression results show that the opening offers made by losers are are highly correlated with their fairness judgments. For winners the variation in fairness judgments cannot explain the variation in opening offers. Note, however, that the constant is with 0.648 close to the proportional split and almost the same as the average fairness judgments made by winners. This is a consequence of the fact that the winners' fairness judgments show relatively little variation and are clustered around the proportional split.

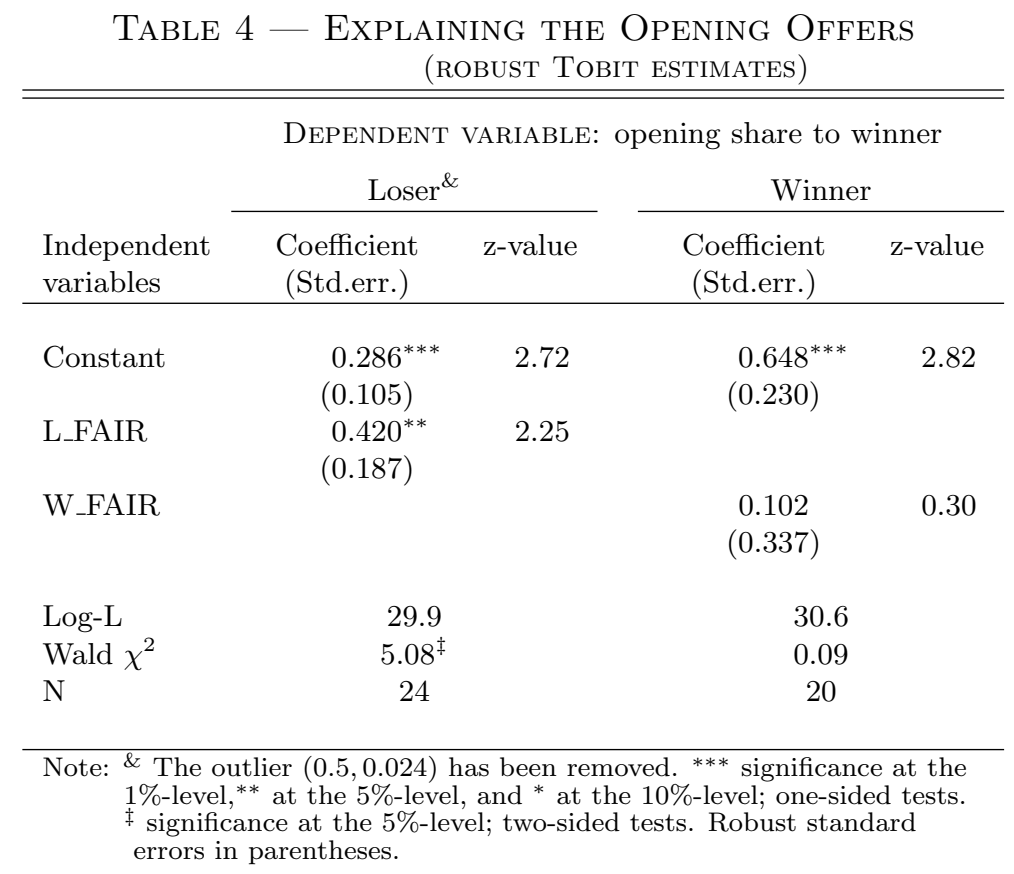

Bargaining duration. The result of regression model 1 in Table 5 resembles the Spearman rank order statistics in the main text. The regression outcome confirms that a higher difference (i.e. tension) in fairness judgments between the winner and the loser in a bargaining pair significantly increases the time till an agreement is reached $(p<0.01$, one-sided). Model 2 shows that this result is robust when taking the difference in first offers (i.e., the difference in the opening offer and the first counter offer) into account. Both the difference in first offers and the difference in fairness judgments signifcantly increase the bargaining duration $(p<0.01$ in both cases, one-sided tests). In Model 3 we investigate how the fairness judgment of the loser and the winner seperately influence 
bargaining duration (again accounting for the difference in first offers). The hypotheses are that the more the loser would give to the winner according to the arbitrator question the faster an agreement is reached. The more the winner would give to the winner according to the arbitrator question the longer it will take to reach an agreement. As the results for Model 3 show both hypotheses are confirmed ( $p=0.10$ and $p<0.01$ for L_FAIR and W_FAIR, respectively). Interestingly the fairness judgment of the winner has a much stronger impact on bargaining duration than that of the loser.

TABle 5 - Explaining Bargaining Duration (ROBUST TOBIT ESTIMATES)

\begin{tabular}{|c|c|c|c|c|c|c|}
\hline \multirow[b]{3}{*}{$\begin{array}{l}\text { Independent } \\
\text { variables }\end{array}$} & \multicolumn{6}{|c|}{ DEPENDENT VARIABLE: agreement time } \\
\hline & \multicolumn{2}{|c|}{ Model 1} & \multicolumn{2}{|c|}{ Model 2} & \multicolumn{2}{|c|}{ Model 3} \\
\hline & $\begin{array}{l}\text { Coefficient } \\
\text { (Std.err.) }\end{array}$ & z-value & $\begin{array}{l}\text { Coefficient } \\
\text { (Std.err.) }\end{array}$ & z-value & $\begin{array}{l}\text { Coefficient } \\
\text { (Std.err.) }\end{array}$ & z-value \\
\hline Constant & $\begin{array}{l}559.9^{* * *} \\
(43.3)\end{array}$ & 12.93 & $\begin{array}{l}436.8^{* * *} \\
(51.8)\end{array}$ & 8.43 & $\begin{array}{c}-282.3 \\
(381.0)\end{array}$ & -0.74 \\
\hline DIFF_FAIR & $\begin{array}{l}1486.9^{* * *} \\
(373.8)\end{array}$ & 3.98 & $\begin{array}{l}1228.3^{* * *} \\
(326.1)\end{array}$ & 3.77 & & \\
\hline L_FAIR & & & & & $\begin{array}{r}-743.2^{*} \\
(451.9)\end{array}$ & -1.65 \\
\hline W_FAIR & & & & & $\begin{array}{l}1869.9^{* * *} \\
(429.4)\end{array}$ & 4.36 \\
\hline DIFF_FIRST & & & $\begin{array}{l}935.3^{* * *} \\
(284.0)\end{array}$ & 3.29 & $\begin{array}{l}1024.1^{* * *} \\
(225.4)\end{array}$ & 4.54 \\
\hline Log-L & -255.8 & & -249 & & -248 . & \\
\hline Wald $\chi^{2}$ & 15.82 & & 34.77 & & 46.52 & \\
\hline $\mathrm{N}$ & 37 & & 37 & & 37 & \\
\hline
\end{tabular}

Concession behavior. Table 6 corroborates the findings reported in the main text. For all our concession statistics - sum of average relative concessions (Model 1), sum of average concession times (Models $2(\mathrm{a})$ and 2(b)), and sum of average time-weighted relative concessions (Model 3) - the difference in fairness judgments (DIFF_FAIR) in a dyad has the 'right' sign and is highly significant $(p<0.01$ in all cases, one-sided tests). Hence, our regression results confirm that the higher the tension in a bargaining pair the smaller concessions are and the later concessions are made. In principle it is possible that concession behavior is also influenced by the first offers. The greater the difference is the more concessions have to be made and/or the larger the concessions have to be to reach an agreement. Our definition of relative concessions accounts for that (see footnote 12). However, it may be the case that the timing of concessions is influenced by the first offers. Therefore, in Model 2(b) we control for the difference in first offers. The result shows that (i) the difference in fairness judgments stays highly significant and (ii) that the difference in first offers indeed has a significant (positive) impact on the concession time ( $p<0.01$ in both cases, one-sided tests). 


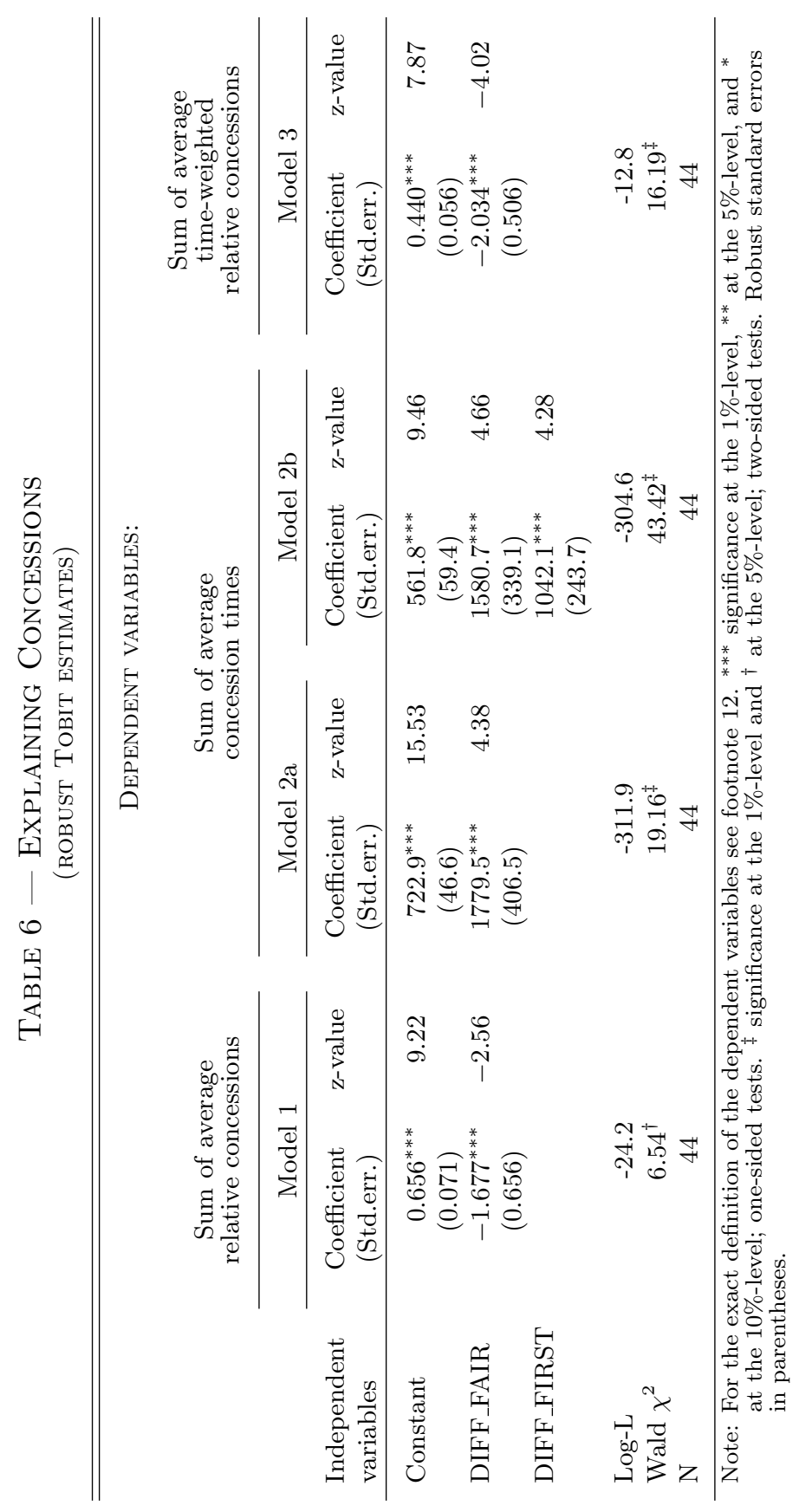


Agreements. In the main text we found with the help of Spearman rank order statistics that the fairness jugdments of losers and winners are significantly positively correlated with the agreement (in winner share) reached in a bargaining pair. The regression results shown in Table 7 corroborate this finding. ${ }^{23}$ The fairness judgment of losers as well as the fairness judgment of winners exhibit a highly significantly positive coefficient $(p<0.01$ for both variables, one-sided tests).

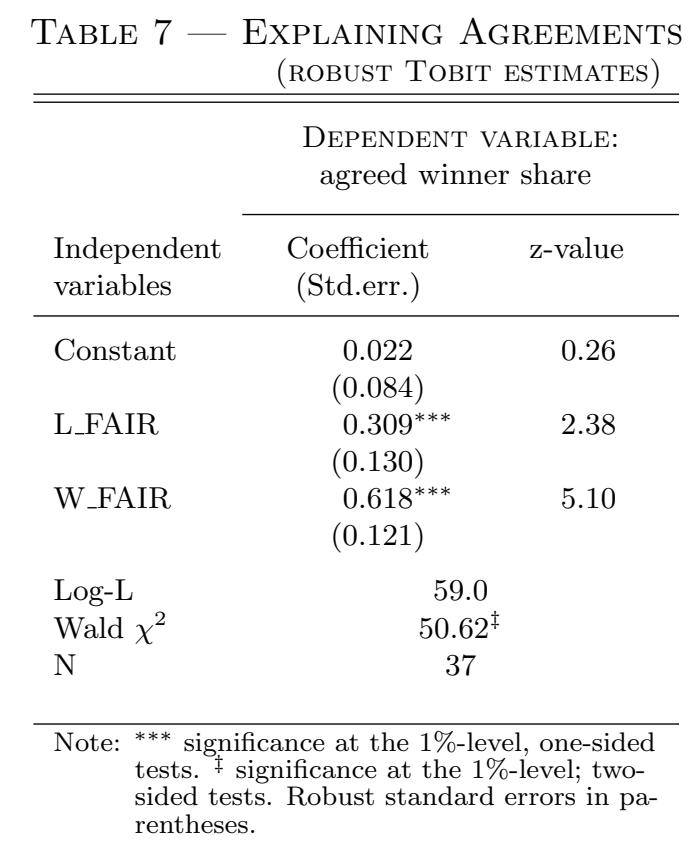

\footnotetext{
${ }^{23}$ In the table L_FAIR represents the losers' fairness judgment and W_FAIR the winners' fairness judgment (both in winner shares).
} 